\title{
Faktor-Faktor yang Mempengaruhi Minat Mahasiswa Menjadi Anggota KSPM UIN Walisongo Semarang dalam Perspektif Islam
}

\author{
Sokhikhatul Mawadah ${ }^{1}$, Fernaldi Anggadha Ratno ${ }^{2}$ \\ ${ }^{1}$ Universitas Islam Negeri Walisongo Semarang \\ ${ }^{2}$ Institut Agama Islam Negeri Salatiga \\ sokhikhatulmawadah@walisongo.ac.id ${ }^{1}$; anggadharatno@iainsalatiga.ac.id ${ }^{2}$
}

\begin{abstract}
This study aims to measure and analyze the influence of religious stimuli, knowledge, creativity and reputation towards interest of becoming a member of KSPM UIN Walisongo Semarang and to see which variables are the most dominant influence in deciding to become members of KSPM UIN Walisongo Semarang. This is field research. The method used to collect the data is questionnaire distributed to the whole population (KSPM board). The dependent variable or variable $Y$ is interest and independent variable or variable $X$ is religious stimuli, knowledge, creativity and reputation. Based on the research result, it can be concluded that first, religious variable of stimuli has positive and significant influence; second, knowledge variable has positive and significant influence; third, creativity variable has not positive influence; and fourth, reputation variable has positive and significant influence and it becomes the most dominant variable in influencing students' interest to become member of KSPM UIN Walisongo Semarang. Primary data was obtained directly from questionnaires distributed to KSPM Walisongo members. Secondary data is obtained from literature, journals, magazines, newspapers, or data related to this research.
\end{abstract}

Keywords: religious stimuli; knowledge; creativity; reputation; interests

\begin{abstract}
Abstrak
Penelitian ini bertujuan untuk mengukur dan menganalisa pengaruh religius stimuli, pengetahuan, kreativitas dan reputasi berpengaruh terhadap minat menjadi anggota KSPM UIN Walisongo Semarang dan melihat variabel mana yang yang paling dominan pengaruhnya dalam memutuskan menjadi anggota KSPM UIN Walisongo Semarang. Penelitian ini merupakan jenis penelitian lapangan, yaitu penelitian dimana informasi dikumpulkan melalui penggunaan kuesioner, dengan melibatkan seluruh populasi (pengurus KSPM) melalui penggunaan kuesioner. Dalam penelitian ini variabel terikat (dependent variable) atau variabel $\mathrm{Y}$ adalah minat dan variabel bebas (independent variable) atau variabel $\mathrm{X}$ adalah religius stimuli, pengetahuan, kreativitas dan reputasi. Berdasarkan hasil penelitian dapat diambil kesimpulan bahwa pertama, variabel religius stimuli terdapat pengaruh yang positif dan signifikan, kedua, variabel pengetahuan terdapat pengaruh yang positif dan signifikan, ketiga variabel kreativitas tidak terdapat pengaruh yang positif, dan keempat, variabel reputasi terdapat pengaruh yang positif dan signifikan serta menjadi variabel yang paling dominan dalam mempengaruhi minat mahasiswa menjadi anggota di KSPM UIN Walisongo Semarang. Penelitian ini merupakan jenis penelitian lapangan, yaitu penelitian dima-
\end{abstract}


na informasi dikumpulkan melalui penggunaan kuesioner, dengan melibatkan seluruh populasi. Data primer diperoleh langsung dari penyebaran kuesioner kepada anggota KSPM Walisongo. Data sekunder diperoleh dari literatur, jurnal, majalah, koran, atau data-data yang berhubungan dengan penelitian.

Kata Kunci: religious stimuli, knowledge, creativity, reputation, interests.

\section{PENDAHULUAN}

Pasar modal syariah di Indonesia mulai lahir setelah secara resmi dibuka oleh Menteri Keuangan Boediono yang didampingi oleh ketua BAPPEPAM Herwidayatmo, wakil dari MUI, wakil DSN dari direksi SRO, direksi perusahaan efek, pengurus organisasi pelaku dan asosiasi profesi di pasar modal Indonesia pada tanggal 14 maret 2003. Sebelumnya, Bapepam telah mengkaji cukup lama berkaitan dengan peresmian pasar modal syariah. Bapepam telah mengirim delegasi untuk studi banding dan melihat mekanisme beroperasinya pasar modal syariah di berbagai pasar modal syariah dunia (Sholahuddin, 2006).

Hadirnya pasar modal syariah di Indonesia diharapkan dapat menjadi tonggak sejarah baru setelah lahirnya Bank Muamalat Indonesia. Meskipun pasar modal syariah belum lama diperkenalkan, namun harapannya dapat diterima masyarakat seperti kehadiran bank syariah dengan lahirnya Bank Muamalat Indonesia, kemunculan reksadana syariah tahun 1997 dan peluncuran Jakarta Islamic Index (JII) pada tahun 2002. Menteri Keuangan Boediono saat peresmian pasar modal syariah mengharapkan dengan munculnya pasar modal syariah ini dapat diikuti hasil karya yang nyata dalam pengembangan instrumen lain yang berbasis syariah.

\section{Profil KSPM (Kelompok Studi Pasar Modal Syariah) UIN Walisongo Semarang}

Hadirnya KSPM merupakan "perpanjangan tangan” adanya lembaga pasar modal syariah yang ada di Indonesia, khususnya Jawa Tengah. KSPM UIN Walisongo Semarang lahir pada 26 Mei 2011. Pendiriannya didasarkan adanya kebutuhan dan keinginan yang kuat dari beberapa mahasiswa Fakultas Ekonomi dan Bisnis Islam (FEBI) UIN Walisongo untuk memiliki wadah dalam mengembangkan soft skill dan hard skill berkaitan dengan kepentingan akademik di luar jam kuliah. Tujuan didirikannya KSPM di lingkungan UIN Walisongo Semarang adalah untuk memperoleh pengetahuan dan ketrampilan tentang ekonomi dan keuangan global pada umumnya dan dunia pasar modal pada khususnya. Pengetahuan tersebut meliputi pengetahuan dan praktik berinvenstasi, menyiapakan dan mendidik para calon praktisi keuangan menjadi investor, agar dapat bersaing setalah lulus dari UIN Walisongo Semarang. (Wawancara dengan Ragil Aprianti, Ketua KSPM, 2017)

KSPM diperuntukan bukan hanya untuk mahasiswa FEBI, namun juga untuk mahasiswa non-FEBI tetapi Pengurus KSPM tahun 2017 ini hanya dari mahasiswa FEBI UIN Walisongo. Oleh karena itu, para pengurus KSPM (mahasiswa yang ikut KSPM) perlu diteliti apakah sesuai pengetahuannya, minatnya, kereligiusannya dalam memilih KSPM sebagai wadah untuk investasi sebagai pengganti peran pasar modal syariah, serta sebagai dasar untuk mengetahui reputasi KSPM di luar UIN Walisongo Semarang dibandingkan dengan pasar modal syariah yang terlebih dahulu ada sebelum KSPM lahir. 
Dalam penelitian ini, penulis memilih KSPM sebagai objek penelitian karena KSPM merupakan perpanjangan tangan pasar modal syariah secara umum untuk kalangan mahasiswa, lokasinya terjangkau, sasaran dan segmennya tepat untuk mahasiswa serta sebagai wadah pengembangan hard skill dan soft skill untuk mahasiswa pada umumnya dan mahasiswa FEBI UIN Walisongo pada khususnya. Dari latar belakang masalah tersebut maka penulis tertarik menelitinya dengan judul "Faktor-Faktor yang Mempengaruhi Minat Mahasiswa menjadi Anggota KSPM UIN Walisongo Semarang".

\section{Teori Minat}

Menurut Tampubolon (1991), minat adalah suatu perpaduan keinginan dan kemauan yang dapat berkembang jika ada motivasi. Sedangkan menurut Djaali (2008) bahwa minat pada dasarnya merupakan penerimaan akan sesuatu hubungan antara diri sendiri dengan sesuatu di luar diri.

Berdasarkan definisi di atas, minat merupakan motivasi yang mendorong orang untuk melakukan apa yang mereka inginkan bila mereka bebas memilih. Bila mereka melihat bahwa sesuatu akan menguntungkan, mereka merasa berminat. Setiap minat akan memuaskan suatu kebutuhan. Dalam melakukan fungsinya kehendak itu berhubungan erat dengan pikiran dan perasaan. Pikiran mempunyai kecenderungan bergerak dalam sektor rasional analisis, sedang perasaan yang bersifat halus/tajam lebih mendambakan kebutuhan.

Menurut Crow \& Crow (dalam Mahmud, 2001), ada tiga faktor yang mempengaruhi timbulnya minat, yaitu:

1. Dorongan dari dalam

Kebutuhan ini dapat berupa kebutuhan yang berhubungan dengan jasmani dan kejiwaan. Misalnya dorongan makan, rasa ingin tahu dan seks.

\section{Motif sosial}

Motif sosial adalah kebutuhan untuk mendapatkan pengakuan, penghargaan dari lingkungan dimana dia berada. Dapat menjadi faktor yang membangkitkan minat untuk melakukan suatu aktivitas tertentu.

\section{Faktor emosional}

Faktor ini merupakan ukuran intensitas seseorang dalam menaruh perhatian terhadap sesuatu kegiatan atau obyek tertentu. Minat mempunyai hubungan yang erat dengan emosi.

\section{Landasan Hukum Bermuamalah dan Bekerja}

\section{Q.S. At Taubah Ayat 105:}

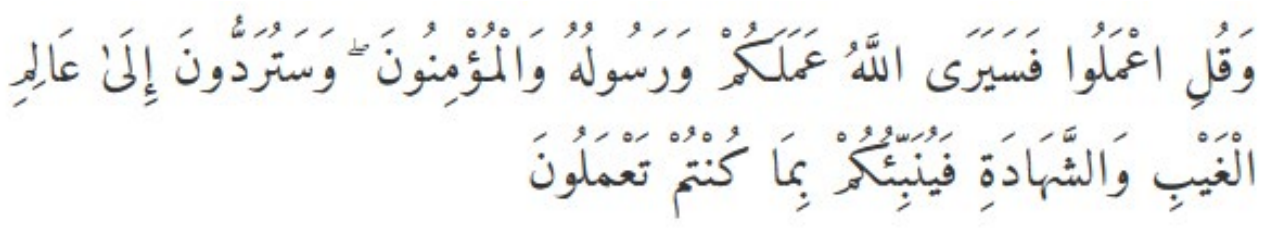

Dan Katakanlah: "Bekerjalah kamu, maka Allah dan Rasul-Nya serta orang-orang mukmin akan melihat pekerjaanmu itu, dan kamu akan dikembalikan kepada (Allah) Yang Mengetahui akan yang ghaib dan yang nyata, lalu diberitakan-Nya kepada kamu apa yang telah kamu kerjakan. 
Islam mengajarkan kepada umatnya agar senantiasa memiliki etos kerja yang tinggi guna memenuhi kebutuhan hidup di dunia dan akhirat. Allah memerintahkan kita untuk bekerja dengan sungguh-sungguh. Islam mengajarkan supaya manusia menjaga keseimbangan antara dunia dan akhirat, dan bekerja dilakukan untuk bekal hidup di akhirat. Hal ini menunjukkan Islam merupakan agama yang dinamis, menuntut umatnya untuk senantiasa bergerak secara produktif, tidak bermalas-malasan. Allah menciptakan alam beserta segala isinya diperuntukkan bagi manusia. Untuk memperoleh manfaat dari alam ini, manusia harus berusaha dan bekerja keras diserta dengan tawakal kepada Allah. Umat Islam harus bekerja keras dalam memenuhi kebutuhan hidupnya termasuk dalam beribadah mendekatkan diri kepada Allah. Hal itu dicontohkan oleh Rasulullah, ketika masih kecil beliau sudah bekerja keras dengan menjadi penggembala dan ketika muda beliau berniaga hingga ke negeri Syam dengan penuh semangat dan jujur. Rasulullah sangat menjunjung tinggi orang yang memenuhi kebutuhannya dengan hasil keringatnya sendiri.

Makna ayat tersebut adalah, seorang mukmin didorong untuk terus bekerja, tidak berdiam diri. Islam tidak memperbolehkan menimbun kekayaan, artinya seseorang yang memiliki harta berlebih hendaknya di distribusikan ke hal yang bermanfaat. Dengan cara membentuk usaha, ditanam di pasar modal, dan sebagainya. Sehingga harta berlebih yang dimiliki seorang mukmin bisa bermanfaat bagi orang lain.

Ayat tersebut menjadi dasar hukum penelitian ini, yang mendorong seseorang untuk terus mendalami pasar modal. Karena pasar modal adalah bentuk ikhtiar seorang mukmin dalam bekerja dan menjadikan harta yang dimiliki bermanfaat bagi orang banyak.

\section{Pengaruh Religius Stimuli Terhadap Minat Mahasiswa Menjadi Anggota KSPM UIN Walisongo}

Menurut Kadir (2003), Religius stimuli merupakan faktor pengetahuan dan pengalaman keberagamaan yang mendorong seseorang untuk melakukan suatu tindakan. Variabel ini memiliki dua dimensi, yaitu dimensi pemahamaan produk dan ketaatan terhadap agama. Produk adalah sesuatu yang dapat ditawarkan ke pasar untuk mendapatkan perhatian untuk dibeli, untuk digunakan atau dikonsumsi yang dapat memenuhi keinginan dan kebutuhan (Rahmawaty, 2008). Produk dari pasar modal syariah ini salah satunya adalah instrumen investasi, seperti saham, obligasi syariah, dan lainnya. Produk bank yang bersifat jasa memiliki karakteristik tersendiri. Oleh karena itu, penentuan produk bank harus benar-benar dikelola secara benar agar masyarakat benarbenar memahami produk-produk yang ditawarkan oleh bank syariah karena produk dan jasa bank konvensional sangat berbeda dengan bank syariah. Ketaatan terhadap agama merupakan tingkat kesadaran dan ketaatan seseorang melakukan apa yang diyakini dalam melaksanakan apa yang diajarkan dalam agama yang telah mereka anut. Karena kesadaran ini merupakan awal dari ekspresi isi dalam kehidupan praktis sebagai pangkal proses perilaku ekonomi religius (Kadir, 2003).

Salah satu penelitian yang berkaitan dengan Religius Stimuli dan Minat adalah penelitian yang berjudul "Faktor-Faktor yang mempengaruhi minat nasabah non muslim menjadi nasabah di Bank Syariah (studi pada Bank CIMB Niaga Syariah Cabang Semarang)" oleh Machmudah (2009). Penelitian ini dimaksudkan untuk mengetahui 
pengaruh faktor-faktor lokasi, pelayanan, religius stimuli, reputasi, profit sharing, promosi terhadap minat. Hasil penelitian ini menunjukkan adanya pengaruh yang signifikan religius stimuli terhadap minat menjadi nasabah bank syariah di Bank CIMB Niaga Syariah Cabang Semarang.

\section{Pengaruh Pengetahuan Terhadap Minat Mahasiswa Menjadi Anggota KSPM UIN Walisongo}

Pengetahuan merupakan hasil dari tahu, dan ini terjadi setelah orang melakukan penginderaan terhadap suatu obyek tertentu. Penginderaan terjadi melalui panca indera penglihatan, pendengaran, penciuman, rasa, dan raba. Menurut Notoatmodjo (2003), pengetahuan atau kognitif adalah faktor paling penting dalam membentuk tindakan.

Lebih lanjut, Notoatmodjo (2003) mengungkapkan bahwa tingkat pengetahuan di dalam kognitif mencakup enam tingkatan, yaitu:

1. Tahu (know)

Tahu diartikan sebagai mengingat suatu materi yang telah dipelajari sebelumnya.

2. Memahami (comprehension)

Memahami diartikan sebagai suatu kemampuan untuk menjelaskan secara benar tentang obyek yang diketahui, dan dapat menginterpretasikan materi tersebut secara benar.

3. Aplikasi (application)

Aplikasi yaitu kemampuan untuk menggunakan materi yang telah dipelajari pada situasi atau kondisi sebenarnya

4. Analisis (analysis)

Analisis adalah suatu kemampuan untuk menjabarkan materi dari suatu obyek ke dalam komponen-komponen

5. Sintesis (synthesis)

Sistensis adalah suatu kemampuan untuk menyusun formulasi baru dari formulasiformulasi yang ada.

6. Evaluasi (evaluation)

Evaluasi berkaitan dengan kemampuan untuk melakukan justifikasi atau penilaian terhadap materi atau obyek.

Salah satu penelitian yang berkaitan dengan Pengetahuan dan Minat adalah penelitian yang berjudul "Pengaruh Sosialisasi dan Pengetahuan terhadap Minat Investor pada Efek Syariah di Pasar Modal (Survei pada Nasabah PT Danareksa Sekuritas Cabang FE-UI Depok)" oleh Khotimah, Warsini \& Nuraeni (2015). Penelitian ini dimaksudkan untuk mengetahui pengaruh sosialisasi dan pengetahuan terhadap minat. Hasil penelitian ini menunjukkan adanya pengaruh yang signifikan pengetahuan terhadap minat investor pada Efek Syariah di Pasar Modal.

\section{Pengaruh Kreativitas Terhadap Minat Mahasiswa Menjadi Anggota KSPM UIN Walisongo}

Kreativitas merupakan salah satu kebutuhan pokok manusia, yaitu kebutuhan akan perwujudan diri (aktualisasi diri) dan merupakan kebutuhan paling tinggi bagi manusia menurut Maslow (dalam Munandar, 2009).

Menurut Guilford (dalam Munandar, 2009), Kreativitas merupakan kemampuan berfikir divergen atau pemikiran menjajaki bermacam-macam alternatif jawaban 
terhadap suatu persoalan yang sama benarnya. Sedangkan menurut Rogers (dalam Zulkarnain, 2002), kreativitas merupakan kecenderungan-kecenderungan manusia untuk mengaktualisasikan dirinya sesuai dengan kemampuan yang dimilikinya.

Ciri-ciri kreativitas menurut Guilford (dalam Munandar, 2009), yaitu:

1. Kelancaran berfikir, yaitu kemampuan untuk menghasilkan banyak ide yang keluar dari pemikiran seseorang secara cepat.

2. Keluwesan berfikir, yaitu kemampuan untuk memproduksi sejumlah ide, jawaban, pertanyaan yang bervariasi, dapat melihat suatu masalah dari sudut pandang yang berbeda dan dapat mencari alternatif.

3. Elaborasi, yaitu kemampuan dalam mengembangkan gagasan dan menambahkan atau memperinci detail-detail dari suatu obyek, gagasan atau situasi sehingga menjadi lebih menarik.

4. Originalitas, yaitu kemampuan untuk mencetuskan gagasan unik atau kemampuan untuk mencetuskan gagasan asli.

Salah satu penelitian yang berkaitan dengan Kreativitas dan Minat adalah penelitian yang berjudul "Pengaruh Pendidikan Kewirausahaan, Kreativitas, dan Motivasi Berwirausaha Terhadap Minat Berwirausaha pada Mahasiswa Pendidikan Ekonomi Universitas Kanjuruhan Malang" oleh Nurikasari (2016). Penelitian ini dimaksudkan untuk mengetahui pengaruh pengaruh pendidikan kewirausahaan, kreativitas, dan motivasi berwirausaha terhadap minat berwirausaha. Hasil penelitian ini menunjukkan adanya pengaruh yang signifikan Kreativitas terhadap minat berwirausaha pada mahasiswa Pendidikan Ekonomi Universitas Kanjuruhan Malang.

\section{Pengaruh Reputasi Terhadap Minat Mahasiswa Menjadi Anggota KSPM UIN Walisongo}

Menurut Basya \& Sati (2006), Reputasi adalah suatu nilai yang diberikan kepada individu, institusi atau negara. Reputasi tidak bisa diperoleh dalam waktu singkat karena harus dibangun bertahun-tahun untuk menghasilkan sesuatu yang bisa dinilai oleh publik. Reputasi juga baru bertahan dan sustainable apabila konsistennya perkataan dan perbuatan.

Reputasi menurut Kamus Besar Bahasa Indonesia adalah nama baik. Reputasi merupakan keseluruhan kualitas dan karakter yang dapat dilihat atau dinilai secara umum oleh masyarakat.

Bagian-bagian yang terdapat dalam reputasi adalah sebagai berikut:

\section{Kompetensi inti}

Kemampuan perusahaan yang memiliki nilai strategis dan menjadi pusat keahlian untuk mewujudkan misi perusahaan atau yang berkontribusi memberikan keuntungan bagi perusahaan.

2. Kredibilitas

Kualitas, kapabilitas, atau kekuatan untuk menimbulkan kepercayaan.

3. Nama baik

Nama baik adalah sesuatu yang harus dipertahankan dan dijaga.

Salah satu penelitian yang berkaitan dengan Reputasi dan Minat adalah penelitian yang berjudul "Pengaruh Reputasi, Kompensasi, dan Lingkungan Kerja Terhadap Minat Melamar Pekerjaan oleh Mahasiswa Universitas Udayana" oleh Permadi \& Netra (2015). Penelitian ini dimaksudkan untuk mengetahui pengaruh reputasi perusahaan, 
kompensasi yang ditawarkan perusahaan dan lingkungan kerja perusahaan terhadap minat melamar pekerjaan. Hasil penelitian ini menunjukkan reputasi memiliki pengaruh yang signifikan terhadap minat melamar pekerjaan

\section{Hipotesis (Rerangka Teori dan Pengembangan Hipotesis)}

Berdasarkan permasalahan, tujuan penelitian dan kerangka berpikir seperti yang telah dijabarkan sebelumnya, dapat dirumuskan hipotesis penelitian ini adalah:

H1: Diduga terdapat pengaruh yang positif dan signifikan variabel religius stimuli terhadap minat mahasiswa menjadi anggota KSPM UIN Walisongo.

$\mathrm{H} 2$ : Diduga terdapat pengaruh yang positif dan signifikan variabel pengetahuan terhadap minat mahasiswa menjadi anggota KSPM UIN Walisongo.

H3: Diduga terdapat pengaruh yang positif dan signifikan variabel kreativitas terhadap minat mahasiswa menjadi anggota KSPM UIN Walisongo.

H4: Diduga terdapat pengaruh yang positif dan signifikan variabel reputasi terhadap minat mahasiswa menjadi anggota KSPM UIN Walisongo.

H5: Diduga dari variabel religius stimuli, pengetahuan, kreativitas dan reputasi, variabel reputasi yang paling dominan dalam mempengaruhi minat mahasiswa menjadi anggota KSPM UIN Walisongo

\section{Kerangka Pemikiran Teoritis} berikut:

Berdasarkan tinjauan pustaka, maka kerangka pemikiran teoritis adalah sebagai

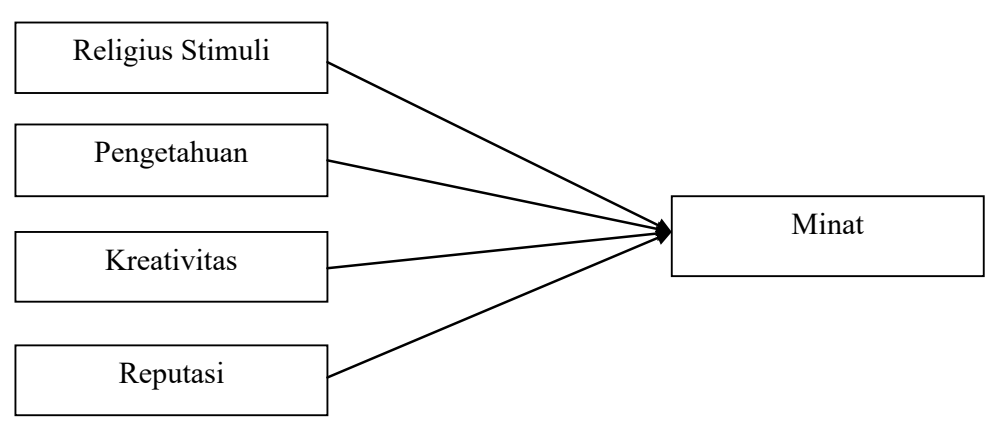

Gambar 1. Kerangka Pemikiran Teoritis

\section{METODOLOGI}

\section{Jenis dan Sumber Data Penelitian}

Penelitian ini merupakan jenis penelitian lapangan, yaitu penelitian dimana informasi dikumpulkan melalui penggunaan kuesioner, dengan melibatkan seluruh populasi. Dalam penelitian ini, peneliti menggunakan metodologi kuantitatif dan sumber data yang digunakan dalam penelitian ini adalah data primer dan data sekunder. Data primer adalah data yang langsung diperoleh dari sumber data pertama di lokasi penelitian atau obyek penelitian (Bungin, 2005). Data primer diperoleh langsung dari penyebaran daftar pertanyaan (kuesioner) kepada anggota KSPM Walisongo. Sedangkan data sekunder adalah data yang diperoleh dari sumber kedua atau sumber sekunder data yang kita butuhkan yang diperoleh dari literatur, jurnal, majalah, koran, dll atau data- 
data yang berhubungan dengan penelitian.

\section{Populasi dan Sampel}

Populasi adalah keseluruhan dari objek penelitian (Arikunto, 2006). Populasi merupakan jumlah dari semua objek atau individu yang akan diteliti. Adapun populasi dalam penelitian ini adalah seluruh anggota KSPM Walisongo Tahun 2017 yaitu sejumlah 80 mahasiswa.

Menurut Sugiyono (2007), Sampel yaitu sebagian dari jumlah dan karakteristik yang dimiliki oleh populasi tersebut. Dapat juga diartikan bagian kecil dari suatu populasi yang karakteristiknya hendak diselidiki dan dianggap dapat mewakili dari keseluruhan populasi atau wakil populasi yang diteliti. Teknik pengambilan sampel yang digunakan dalam penelitian ini adalah non-problability sampling, yaitu sampling jenuh. Sampling jenuh adalah teknik penentuan sampel bila semua anggota populasi digunakan sebagai sampel menurut Sugiyono (2007). Maka jumlah sampel yang diteliti adalah sejumlah 80 responden.

\section{Variabel Penelitian}

Variabel yang digunakan dalam penelitian ini adalah:

1) Variabel bebas (variabel independent)

Variabel bebas dalam penelitian ini adalah religius stimuli (X1), pengetahuan (X2), kreativitas (X3) dan reputasi (X4).

2) Variabel tergantung (variabel dependent)

Variabel Terikat dalam penelitian ini adalah minat mahasiswa (Y).

\section{HASIL PENELITIAN}

\section{Uji Regresi Berganda}

Dengan melihat tabel di atas, dapat dirumuskan persamaan regresi adalah sebagai berikut:

Keterangan :

$$
\text { Minat }=4,797+0,094 X_{1}+0,139 X_{2}-0,129 X_{3}+0,648 X_{4}
$$

1. Dari model regresi linear berganda diatas dapat diketahui nilai konstanta sebesar 4,797 artinya bila variabel bebas antara lain religius stimuli (X1), pengetahuan (X2), kreativitas (X3), reputasi (X4) konstantanya sebesar NOL maka minat (Y) mempunyai nilai sebesar 4, 797.

2. Variabel religius stimuli (X1) pada model regresi linear berganda diatas nilai koefisien yang dihasilkan sebesar 0,094 artinya apabila religius stimuli meningkat 1 satuan dan yang lain NOL, maka akan meningkatkan minat sebesar 0,094.

3. Variabel pengetahuan (X2 pada model regresi linear berganda diatas nilai koefisien yang dihasilkan sebesar 0,139 , artinya apabila pengetahuan meningkat 1 satuan dan yang lain NOL, maka akan meningkatkan minat sebesar 0,139 .

4. Variabel kreativitas (X3) pada model regresi linear berganda diatas nilai koefisien yang dihasilkan sebesar -0,129, artinya apabila kreativitas mengalami peningkatan 1 satuan dan yang lain NOL, maka nilai minat diprediksi turun sebesar 0,129. 
5. Variabel reputasi (X4) pada model regresi linear berganda diatas nilai koefisien yang dihasilkan sebesar 0,648 , artinya apabila reputasi meningkat 1 satuan dan yang lain NOL, maka akan meningkatkan minat sebesar 0,648.

\section{Hipotesis}

\section{Uji $t$}

Diketahui bahwa $\mathrm{t}$ tabel adalah adalah 1,664, $\mathrm{t}$ hitung variabel religius stimuli, pengetahuan, dan reputasi lebih besar daripada $t$ tabel, sedangkan variabel kreativitas lebih kecil. Maka variabel religius stimuli, pengetahuan, dan reputasi berpengaruh terhadap variabel minat, sedangkan variabel kreativitas tidak berpengaruh.

Dari ketiga variabel yang berpengaruh tersebut, variabel reputasilah yang memiliki pengaruh yang terbesar terhadap minat. Maka variabel reputasi yang paling dominan pengaruhnya terhadap minat.

\section{Uji Koefisien Determinasi $\left(R^{2}\right)$}

Berdasarkan hasil penelitian dapat diketahui bahwa koefisien determinasi yang ditunjukkan dari nilai adjusted $R$ square sebesar 0,921. Hal ini menunjukkan bahwa $92,1 \%$ variabel dependen minat dapat dijelaskan oleh variabel independen (variabel religius stimuli pengetahuan, kreativitas, dan reputasi) sedangkan sisanya sebesar 7,9\% dipengaruhi oleh variabel-variabel lain yang tidak terdapat dalam penelitian ini.

\section{PEMBAHASAN}

\section{Religius Stimuli}

Hasil persamaan regresi diketahui bahwa variabel religius stimuli berpengaruh positif dan signifikan terhadap minat mahasiswa menjadi anggota KSPM Walisongo. Hal ini sejalan dengan penelitian yang dilakukan oleh Machmudah (2009). Dalam kajiannya tersebut disebutkan bahwa religius stimuli mempengaruhi minat menjadi nasabah. Dalam perspektif teori, yaitu perspektif motif emosional menurut Peter \& Olson (2005), religius stimuli dapat dikategorikan sebagai bagian dari aspek emosi seseorang dalam memilih. Motif emosional adalah motif keputusan yang berkaitan dengan perasaan atau emosi individu, seperti pengungkapan rasa cinta, kebanggaan, kenyamanan, kesehatan, keamanan dan kepraktisan. Pada umumnya motif emosional ini bersifat subyektif.

Dalam penelitian ini, ukuran subyektivitas tersebut akan berkaitan dengan sejauh mana persepsi masing-masing mahasiswa terhadap kesesuaian produk dan layanan yang ada pada galeri pasar modal syariah dengan keinginan mahasiswa. Ketaatan kepada agama sebagai alasan menggunakan galeri pasar modal syariah merupakan hal yang dapat di interpretasikan secara beragam oleh masing-masing individu. Diantaranya adalah perbedaan persepsi tentang skala urgensi menggunakan jasa pasar modal syariah daripada pasar modal konvensional demi merealisasikan nilai-nilai ketaatan. Dalam konteks ini ada perbedaan persepsi dan keyakinan tentang sejauh mana galeri pasar modal syariah merepresentasikan nilai-nilai ketaatan. Hal ini menunjukkan bahwa semakin tinggi religius stimuli, maka minat mahasiswa menjadi anggota KSPM akan semakin besar 


\section{Pengetahuan}

Hasil persamaan regresi diketahui bahwa variabel pengetahuan berpengaruh positif dan signifikan terhadap minat mahasiswa menjadi anggota KSPM Walisongo. Hal ini menunjukkan bahwa semakin tinggi tingkat pengetahuan mahasiswa tentang pasar modal, maka minat mahasiswa menjadi anggota KSPM akan semakin besar. Penelitian ini sejalan dengan penelitian Khotimah et al. (2015). Pengetahuan memiliki peran penting dalam meningkatkan minat seseorang. Tanpa pengetahuan yang memadai minat seseorang akan rendah.

Tingkat pengetahuan mahasiswa tentang pasar modal, dapat dilihat dengan cara: melakukan sosialisasi dan edukasi. Sosialisasi dilakukan dengan cara mengadakan "open table" seperti: recruitment di tempat-tempat strategis di kampus yang sering dilalui mahasiswa, menyebar brosur, menjelaskan apabila ada mahasiswa lain yang bertanya. Sedangkan edukasi dilakukan dengan cara: seminar, workshop dan pelatihan dengan menggandeng praktisi yang ahli dibidangnya. Selain itu melakukan pelatihan yang rutin kepada mahasiswa UIN Walisongo. Melalui cara ini minat mahasiswa terhadap KSPM UIN Walisongo bisa bertambah, karena pengetahuan mereka tentang pasar modal syariah juga bertambah.

\section{Kreativitas}

Hasil persamaan regresi diketahui bahwa variabel kreativitas berpengaruh negatif terhadap minat mahasiswa menjadi anggota KSPM Walisongo. Dengan kata lain variabel kreativitas tidak berpengaruh terhadap minat mahasiswa menjadi anggota KSPM. Hal ini tidak sejalan dengan penelitian yang dilakukan oleh Nurikasari (2016). Dalam kajiannya menyebutkan bahwa kreativitas dapat mempengaruhi minat seseorang.

Tidak adanya pengaruh ini, menunjukkan bahwa kreativitas mahasiswa UIN Walisongo perlu ditingkatkan. Hal tersebut karena minimnya sarana dan prasarana yang dimiliki oleh KSPM. Peningkatan kreativitas mahasiswa anggota KSMP dapat dilakukan dengan beberapa cara, salah satunya dengan melakukan pembinaan dan pemberian perhatian dari pihak kampus dalam rangka meningkatkan minat terhadap pasar modal syariah. Perhatian yang riil adalah dengan menjadikan KSPM sebagai lembaga dibawah naungan fakultas, bukan lembaga independen bentukan mahasiswa yang tidak mendapat dana dari fakultas. Cara lain adalah melalui penciptaan iklim pembelajaran yang lebih kreatif di kelas. Iklim belajar kreatif melalui pemberian kesempatan yang bebas kepada mahasiswa dalam menyampaikan ide-ide atau gagasannya terkait dengan pasar modal syariah. Berdasarkan penelitian Nurikasari tersebut, kreativitas menimbulkan hal yang besar dalam seseorang dan bahkan dapat mempengaruhi minat seseorang.

\section{Reputasi}

Hasil persamaan regresi diketahui bahwa variabel reputasi berpengaruh positif dan signifikan terhadap minat mahasiswa menjadi anggota KSPM Walisongo. Hal ini menunjukkan bahwa semakin baik reputasi KSPM, maka pasar modal syariah juga akan dipandang baik sehingga minat mahasiswa menjadi anggota KSPM akan semakin besar. Hal ini sejalan dengan penelitian yang dilakukan oleh Permadi \& Netra (2015). Dalam kajiannya tersebut disebutkan bahwa reputasi mempengaruhi minat melamar pekerjaan.

Reputasi bisa jadi merupakan suatu penilaian yang sangat subyektif dan akan berbeda diantara masing-masing individu, tergantung parameter yang digunakan. 
Masyarakat dapat menilai, salah satunya melalui kompetensi inti pasar modal syariah. Kompetensi tersebut yaitu pada prinsip-prinsip syariah yang operasionalnya secara umum sejalan dengan konsep Islam dalam pemerataan dan peningkatan kemakmuran. Prinsip syariah pada dasarnya bertujuan untuk memastikan keadilan dalam sebuah transaksi. Hal tersebut berdampak pada perlindungan hak-hak terkait atas eksploitasi, penipuan, maupun ketidakadilan antara imbal balik dalam melakukan transaksi. Pasar modal syariah menawarkan akses yang lebih luas bagi perusahaan dalam rangka mengembangkan usahanya. Selain itu, melalui prinsip operasional tersebut, pasar modal syariah disebut sebagai salah satu alternatif investasi yang lebih baik dibandingkan dengan yang lainnya.

\section{Variabel yang Paling Dominan Pengaruhnya Terhadap Minat}

Variabel reputasi merupakan variabel yang paling dominan pengaruhnya terhadap minat mahasiswa menjadi anggota KSPM UIN Walisongo. Dibandingkan dengan variabel religius stimuli, pengetahuan, dan kreativitas, variabel reputasi paling besar pengaruhnya terhadap minat. Hal ini sejalan dengan penelitian yang dilakukan oleh Permadi \& Netra (2015). Variabel reputasi memiliki pengaruh yang positif terhadap minat. Reputasi besar UIN Walisongo Semarang, menjadikan reputasi KSPM nya juga sama besarnya. Berdasarkan kualitas, kapabilitas para pengelola/anggota KSPM. Dengan cara tersebut mahasiswa akan mempertahankan kepercayaannya. Selain itu, reputasi KSPM akan sangat menentukan eksistensinya di UIN Walisongo. Reputasi atau nama baik pasar modal syariah khususnya KSPM UIN Walisongo sangat mempengaruhi minat mahasiswa untuk menjadi anggota. Apabila reputasinya menurun makan minat mahasiswa juga akan menurun.

\section{KESIMPULAN}

Berdasarkan hasil penelitian yang dilakukan maka dapat diambil kesimpulan bahwa terdapat pengaruh yang signifikan dari variabel religius stimuli terhadap minat mahasiswa menjadi anggota KSPM UIN Walisongo Semarang. Hal ini didasarkan pada pengujian secara individual (uji t) yang menghasilkan nilai ${ }_{\text {hitung }}$ sebesar 3,055 dan signifikansi sebesar 0,003 . Oleh karena nilai $t_{\text {hitung }}>t_{\text {tabel }}(=1,664)$, maka dapat disimpulkan bahwa Ho ditolak dan Ha diterima. Sementara itu, nilai signifikansi yang diketahui $<0,05$ (nilai kritis pada $\alpha=5 \%$ ) menegaskan bahwa pengaruh yang diberikan oleh religius stimuli (X1) secara individual terhadap minat mahasiswa menjadi anggota KSPM UIN Walisongo Semarang adalah signifikan (nyata). Terdapat pengaruh yang signifikan dari variabel pengetahuan terhadap minat mahasiswa menjadi anggota KSPM UIN Walisongo Semarang. Hal ini didasarkan pada pengujian secara individual (uji t) yang menghasilkan nilai $\mathrm{t}_{\text {hitung }}$ sebesar 2,981 dan signifikansi sebesar 0,004. Oleh karena nilai $\mathrm{t}_{\text {hitung }}>\mathrm{t}_{\text {tabel }}(=1,664)$, maka dapat disimpulkan bahwa Ho ditolak dan Ha diterima. Sementara itu, nilai signifikansi yang diketahui $<0,05$ (nilai kritis pada $\alpha=5 \%$ ) menegaskan bahwa pengaruh yang diberikan oleh pengetahuan (X2) secara individual terhadap minat mahasiswa menjadi anggota KSPM UIN Walisongo Semarang adalah signifikan (nyata). Tidak terdapat pengaruh yang signifikan dari variabel kreativitas terhadap minat mahasiswa menjadi anggota KSPM UIN Walisongo Semarang. Hal ini didasarkan pada pengujian secara individual (uji t) yang menghasilkan nilai ${ }_{\text {hitung }}$ sebesar 
$-1,827$ dan signifikansi sebesar 0,072. Oleh karena nilai $\mathrm{t}_{\text {hitung }}<\mathrm{t}{ }_{\text {tabel }}(=1,664)$, maka dapat disimpulkan bahwa Ho diterima dan Ha ditolak. Sementara itu, nilai signifikansi yang diketahui $>0,05$ (nilai kritis pada $\alpha=5 \%$ ) menegaskan bahwa pengaruh yang diberikan oleh kreativitas (X3) secara individual terhadap minat mahasiswa menjadi anggota di KSPM UIN Walisongo Semarang adalah tidak signifikan (tidak nyata). Terdapat pengaruh yang signifikan dari variabel reputasi terhadap minat mahasiswa menjadi anggota KSPM UIN Walisongo Semarang. Hal ini didasarkan pada pengujian secara individual (uji t) yang menghasilkan nilai $\mathrm{t}_{\text {hitung }}$ sebesar 10,426 dan signifikansi sebesar 0,000. Oleh karena nilai $\mathrm{t}_{\text {hitung }}>\mathrm{t}_{\text {tabel }}(=1,664)$, maka dapat disimpulkan bahwa Ho ditolak dan Ha diterima. Sementara itu, nilai signifikansi yang diketahui $<0,05$ (nilai kritis pada $\alpha=5 \%$ ) menegaskan bahwa pengaruh yang diberikan oleh reputasi (X4) secara individual terhadap minat mahasiswa menjadi anggota KSPM UIN Walisongo Semarang adalah signifikan (nyata). Variabel reputasi menjadi variabel yang paling dominan dalam mempengaruhi minat minat mahasiswa menjadi anggota KSPM UIN Walisongo Semarang. Hal ini didasarkan pada hasil pengujian secara individual (uji t) yang menunjukkan bahwa variabel reputasi memiliki nilai $t_{\text {hitung }}>\mathrm{t}$ tabel dan nilai signifikansi $<0,05$ serta variabel reputasi memiliki nilai $\mathrm{t}$ hitung yang tertinggi dibandingkan dengan variabel religius stimuli, pengetahuan, dan kreativitas. Selain itu, variabel reputasi memiliki nilai signifikansi yang terendah dibandingkan dengan variabel lainnya.

\section{DAFTAR PUSTAKA}

Arikunto, S. (2006). Prosedur Penelitian Suatu Pendekatan Praktik. Jakarta: Rineka Cipta.

Basya, M., \& Sati. I. (2006). Tantangan Indonesia Baru: Strategi dan Aktivitas Public Relations. Jakarta: Perhumas.

Bungin, M. B. (2005). Metodologi Penelitian Kuantitatif. Jakarta: Prenada Kencana Group.

Djaali. (2008). Psikologi Pendidikan. Jakarta: CV Pendoman Ilmu Jaya.

Kadir, A. (2003), Konsep dan Tuntunan Praktis Basis Data. Yogyakarta: Andi.

Khotimah, H., Warsini, S., \& Nuraeni, Y. (2015). Pengaruh Sosialisasi dan Pengetahuan terhadap Minat Investor pada Efek Syariah di Pasar Modal (Survei pada Nasabah PT Danareksa Sekuritas Cabang FE-UI Depok). Jakarta. Account: Jurnal Akuntansi, Keuangan dan Perbankan Politeknik Negeri Jakarta, 1(1).

Mahmud, D. (2001). Psikologi Suatu Pengantar. Yogyakarta: BPFE

Machmudah, R. (2009). Faktor-Faktor Yang Mempengaruhi Minat Nasabah Non Muslim Menjadi Nasabah Di Bank Syariah (Studi Pada Bank CIMB Niaga Syariah Cabang Semarang). Semarang: Skripsi Jurusan Ekonomi Islam Fakultas Syariah Institut Agama Islam Negeri Walisongo Semarang.

Munandar, U. (2009). Pengembangan Kreativitas Anak Berbakat. Jakarta: Rineka Cipta.

Notoatmodjo, S. (2003). Pendidikan dan Perilaku Kesehatan. Jakarta: Rineka Cipta.

Nurikasari, F. (2016). Pengaruh Pendidikan Kewirausahaan, Kreativitas, Dan Motivasi Berwirausaha Terhadap Minat Berwirausaha Pada Mahasiswa Pendidikan Ekonomi Universitas Kanjuruhan Malang. Malang: Jurnal Fakultas Ekonomika dan Bisnis Universitas Kanjuruhan Malang.

Permadi, K. D.. \& Netra, I. G. S. K. (2015). Pengaruh Reputasi, Kompensasi, dan Lingkungan Kerja Terhadap Minat Melamar Pekerjaan Oleh Mahasiswa Universitas Udayana. E-Jurnal Manajemen Unud, 4(1).

Peter, P. J., \& Olson, J. C. (2005). Consumer Behavior and Marketing Strategy. New York: 
153 Sokhikhatul M, Fernaldi A.R., Faktor-Faktor yang Mempengaruhi Minat Mahasiswa...

Irwin/Mc Graw Hill.

Rahmawaty, A. (2008). Analisis Pemicu Perbedaan Motivasi Nasabah Berafiliasi Antara Bank Konvensional dan Bank Syari’h di Semarang. Kumpulan Makalah ACIS "Penguatan Peran Perguruan Tinggi Agama Islam dalam Meningkatkan Daya Saing Bangsa”. Palembang.

Sholahuddin. (2006). Lembaga Ekonomi dan Keungan Islam. Surakarta: Muhammadiyah University Press.

Sugiyono. (2007). Metode Penelitian Pendidikan Pendekatan Kuntitatif dan Kualitatif dan R \& D. Bandung: Alfa Beta.

Tampubolon. (1991). Mengembangkan Minat dan Kebiasaan Membaca Pada Anak. Bandung: Angkasa.

Zulkarnain. (2002). Kreativitas dan Kontrol Diri. Jakarta: Rineka Cipta. 